\title{
15. GEOCHEMISTRY AND PROVENANCE OF BASALTIC CLASTS WITHIN VOLCANICLASTIC DEBRIS FLOWS, EAST MARIANA BASIN, DEEP SEA DRILLING PROJECT SITE 585 ${ }^{1}$
}

\author{
P. A. Floyd, Department of Geology, University of Keele ${ }^{2}$
}

\begin{abstract}
Pebble-sized basaltic and glassy clasts were extracted from seamount-derived volcaniclastic debris flows and analyzed for various trace elements, including the rare earths, to determine their genetic relationships and provenance. All the clasts were originally derived from relatively shallow submarine lava flows prior to sedimentary reworking, and have undergone minor low-grade alteration. They are classified into three petrographic groups (A, B, and C) characterized by different phenocryst assemblages and variable abundances and ratios of incompatible elements. Group A (clast from Hole 585) is a hyaloclastite fragment which is olivine-normative and distinct from the other clasts, with incompatibleelement ratios characteristic of transitional or alkali basalts. Groups B and C (clasts from Hole 585A) are quartz-normative, variably plagioclase-clinopyroxene-olivine phyric tholeiites, all with essentially similar ratios of highly incompatible elements and patterns of enrichment in light rare earth elements (chrondrite-normalized). Variation within Groups B and C was governed by low-pressure fractionation of the observed phenocryst phases, whereas the most primitive compositions of each group may be related by variable partial melting of a common source. The clasts have intraplate chemical characteristics, although relative to oceanic hot-spot-related volcanics (e.g., Hawaiian tholeiites) they are marginally depleted in most incompatible elements. The source region was enriched in all incompatible elements, compared with a depleted mid-ocean-ridge basalt source.
\end{abstract}

\section{INTRODUCTION}

In common with many other DSDP sites in the western Pacific, Site 585 of Leg 89 in the East Mariana Ba$\sin$ (Fig. 1) has thick sequences of Cretaceous volcaniclastic sediments derived from adjacent seamounts. The widespread and long-lived nature of the Cretaceous volcanic episode on some of the oldest Pacific Ocean crust implies the existence of a large lithospheric thermal anomaly during this time interval (Larson and Schlanger, 1981; Haggerty et al., 1982). Although edifice-building was a major feature of Cretaceous volcanism, it cannot be readily related to accepted hot-spot theories of the generation of oceanic islands or seamounts (Schlanger and Premoli Silva, 1981). If this is the case, the basaltic clasts within the volcaniclastics sampled at Site $\mathbf{5 8 5}$ may represent a different form of intraplate volcanism, and may show petrological and chemical features distinct from those of typical plume-related volcanism (e.g., the Hawaiian chain).

The objectives of this paper are to identify the petrological and chemical characteristics of basaltic clasts and assess their genetic relationships, and to compare them with the products of typical hot-spot-generated basalts. In a sense, the clasts that were large enough to be extracted whole for analysis can be regarded in the same way as the individual samples of a dredge haul. This report, however, is only preliminary, because few samples are available and comparisons are limited by the paucity of data.

\footnotetext{
${ }^{1}$ Moberly, R., Schlanger, S. O., et al., Init. Repts. DSDP, 89: Washington (U.S. Govt. Printing Office).

2 Address: Dept. of Geology, University of Keele, Staffordshire, U.K. ST5 SBG.
}

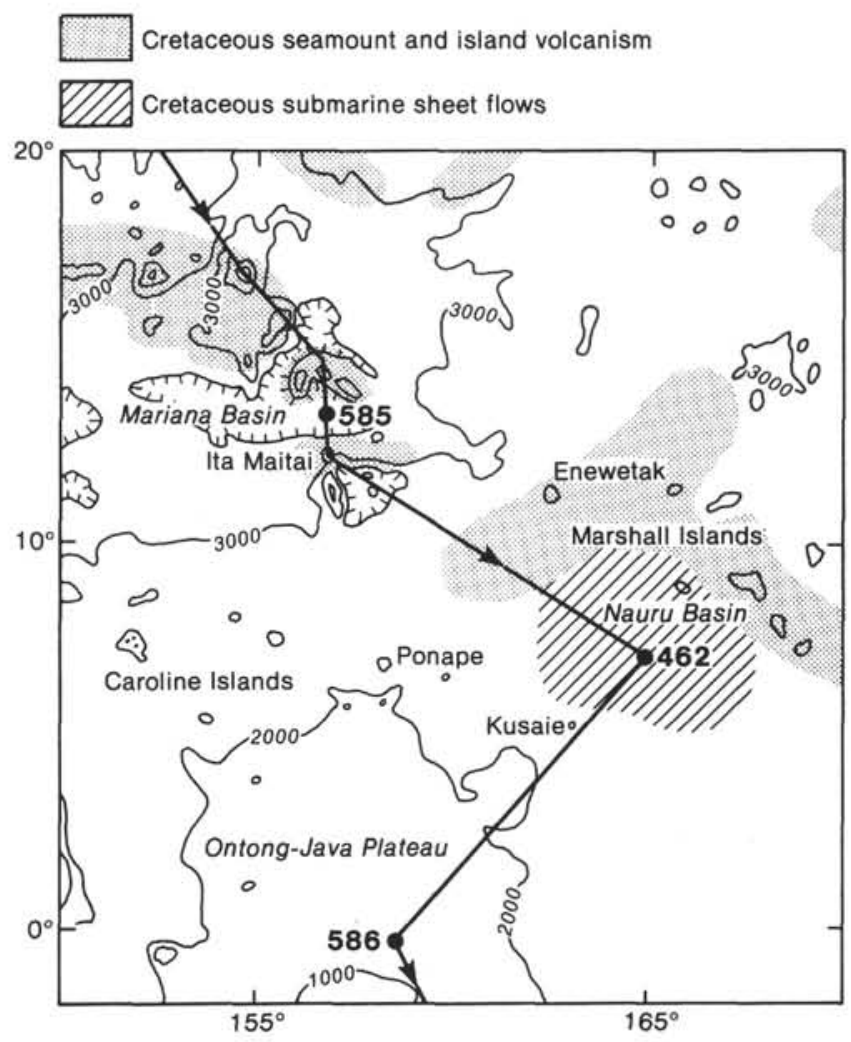

Figure 1. Location of Site 585 in the East Mariana Basin, western Pacific, and distribution of local Cretaceous volcanism (after Winterer, 1973).

\section{ANALYTICAL METHODS}

Nine clasts of between 20 and $60 \mathrm{~cm}^{3}$ volume were extracted from selected cores and analyzed for major and trace elements by X-ray fluorescence (XRF) spectometry (detailed by Floyd, this volume). Each 
sample was also analyzed for the rare earth elements (REE) by induced coupled plasma (ICP) spectrometry at Kings College, London (Walsh et al., 1981) and for Hf, Ta, Th, and U by instrumental neutron activation analysis (INAA) at the Universities Research Reactor, Risley (Duffield and Gilmore, 1979). The light REE were also analyzed by XRF, and the results compare favorably with the ICP data; both sets of data are presented, although only the ICP results are used in the normalized multi-element diagrams. Analytical precision of XRF analysis, determined by the replicate analysis of a standard, was \pm 1 to $\pm 4 \%$ for major elements and less than $\pm 5 \%$ for trace elements, except $\mathrm{La}, \mathrm{Ce}$, and $\mathrm{Nb}( \pm 10 \%)$.

\section{VOLCANIC STRATIGRAPHY}

The oldest stratigraphic unit of Holes 585 and 585A (lithologic Unit VI, site chapter, this volume) is composed of relatively coarse, graded volcaniclastic sediments swept from the flanks of seamounts into the southern Mariana Basin by mass flow mechanisms. The sediments are mainly the products of turbidity currents (Whitman et al., this volume), although in Hole $585 \mathrm{~A}$ there is a major unit of debris flows characterized by larger than usual clasts. Most of the volcaniclastics are mixed lithic and vitric tuffs and lapillistones, but within the debris flows of Hole 585A there are thin agglomeratic layers containing rounded pebble-sized and rarer cobble-sized clasts. Except for one additional clast from Hole 585, all samples for analysis were extracted from this unit. All the volcaniclastics are representative of reworked hyaloclastites originally erupted into shallow water, and can be divided into different variably phyric petrographic groups (Floyd, this volume).

\section{PETROLOGY OF EXTRACTED CLASTS}

The locations, lithologies and DSDP sample numbers of the nine extracted clasts (hereafter numbered 1 to 9 in text and diagrams) are given in Table 1; the clasts are either hypocrystalline basalts or hyaloclastites composed of cemented glass fragments (Plate 1). Both clast types are poorly vesicular to nonvesicular $(0-15 \mathrm{vol} . \%)$, and on the basis of petrographic and chemical features can be divided into three groups: (1) plagioclase-clinopyroxene-olivine phyric glass (sample 1), (2) moderately palgioclase-olivine-phyric glass and basalt (samples 2, 5, 6 ), and (3) sparsely to moderately plagioclase-phyric glass and basalt (samples 3, 4, 7-9).

\section{Group A: Plagioclase-Clinopryoxene-Olivine Phyric}

This group is represented by only a single hyaloclastite pebble extracted from Hole 585, and is petrographically distinctive in containing both microphenocrysts and megaphenocrysts of plagioclase and clinopyroxene, and occasional rare olivine microphenocrysts. By far the greater part of the clast consists of glassy shards cemented by a fine smectitic matrix, which was also initially vitric. A few lithic fragments $(\sim 5 \%)$ of a titanaugite-bearing plagioclase-phyric basalt also occur. The glass shards are represented by both clear, highly vesicular (40-50 vol.\%) sideromelane and golden yellow-brown or greenish palagonite replacing original, less vesicular $(10-20 \mathrm{vol} . \%)$ glass. Most of the palagonite exhibits alteration zoning with an outer pale green rim and internal zones marked by dark brown granular material of variable translucency, and finally a dark green core. The brownish material, when not opaque and masking any birefringence, appears to be smectitic, and replaces the palagonite.

The olivine microphenocrysts are euhedral and more often than not replaced by smectite. Plagioclase occurs as lath-shaped microphenocrysts and subhedral megacrysts, both of which are replaced by bright green smectite or celadonite. Clinopyroxene megacrysts constitute the only unaltered crystal phase in the rock, and are generally calcic augites. Not every vitric fragment in this sample may contain all three phenocrysts, but the various associations suggest that the fragments were all derived originally from a single flow or eruptive unit.

\section{Group B: Plagioclase-Olivine-Phyric}

The two basalt clasts in this group are generally poorly vesicular and very fine-grained, commonly exhibiting quench textures and dark smectite-replaced interstitial glass and associated magnetite. Matrix clinopyroxene may occur as feathery crystallites or may be granular in habit, whereas plagioclase is microlithic with some forked terminations. Vesicles are commonly irregular $(0.1-0.3 \mathrm{~mm}$ diameter) in shape, with zones of dirty pale lime green or brownish smectite on the walls and a core of radiate fibrous pleochroic dark green smectite. Plagioclase phe-

Table 1. Reference data on analyzed clasts extracted from volcaniclastic debris flows, Site 585, East Mariana Basin.

\begin{tabular}{|c|c|c|c|c|c|c|}
\hline $\begin{array}{l}\text { Sample } \\
\text { number }^{\mathrm{a}}\end{array}$ & $\begin{array}{l}\text { DSDP sample number } \\
\text { (interval in } \mathrm{cm} \text { ) }\end{array}$ & $\begin{array}{l}\text { Sub-bottom } \\
\text { depth } \\
\text { (m) }\end{array}$ & $\begin{array}{c}\text { Volcanic } \\
\text { unit }\end{array}$ & $\begin{array}{l}\text { Petrographic } \\
\text { group }\end{array}$ & & Lithology \\
\hline 1 & $585-48-1,141-144$ & 687.53 & 4 & A & & $\begin{array}{l}\text { Hyaloclastite composed of variably plagioclase- } \\
\text { clinopyroxene-olivine phyric glass and pa- } \\
\text { lagonite }\end{array}$ \\
\hline 2 & $585 \mathrm{~A}-18-7,46-50$ & 857.18 & 6 & B & & $\begin{array}{l}\text { Zeolitized hyaloclastite composed of sparsely } \\
\text { plagioclase-phyric palagonite }\end{array}$ \\
\hline 3 & $585 \mathrm{~A}-20-2,121-123$ & 869.54 & 6 & $\mathrm{C}$ & & Sparsely plagioclase-phyric hypocrystalline ba- \\
\hline 4 & $585 \mathrm{~A}-20-2,124-128$ & 869.58 & 6 & C & & salts \\
\hline 5 & $585 \mathrm{~A}-21-1,1-4$ & 876.03 & 6 & B & & Poorly vesicular, moderately plagioclase-oliv- \\
\hline 6 & $585 \mathrm{~A}-21-2,52-58$ & 878.05 & 6 & B & \} & ine-phyric fine-grained basalts \\
\hline 7 & $585 \mathrm{~A}-21-2,61-65$ & 878.13 & 6 & $\mathrm{C}$ & & $\begin{array}{l}\text { Moderately plagioclase-phyric hypocrystalline } \\
\text { basalt }\end{array}$ \\
\hline 8 & $585 \mathrm{~A}-22, \mathrm{CC}(34-40)$ & 887.45 & 7 & $\mathrm{C}$ & & Hyaloclastites composed of moderately plagio- \\
\hline 9 & $585 \mathrm{~A}-22, \mathrm{CC}(49-52)$ & 887.60 & 7 & C & & clase-phyric palagonite \\
\hline
\end{tabular}

\footnotetext{
${ }^{a}$ Number used in text and diagrams.
} 
nocrysts occur in two morphologies, thin laths $(0.5 \mathrm{~mm}$ long) and megacrysts (1-2 mm long), both of which can be replaced axially by lime-green smectite. Pseudomorphs after olivine phenocrysts $(0.5-1.5 \mathrm{~mm})$ have been identified by their pseudohexagonal outlines and by replacement products such as greenish brown or brown smectite, together with minor carbonate and zeolite. Some pseudomorphs may show a distinctive microveining of alteration products.

One glass clast is included in this group on the basis of chemical composition rather than petrographic criteria, since olivine has not been identified and plagioclase is relatively scarce. In part, this may be because the glass has been replaced initially by a granular dark brown palagonite and then subsequently by zeolite that masks internal features. The matrix within which the shards are set is also heavily zeolitized.

\section{Group C: Plagioclase-Phyric}

Five clasts are assigned to this group: two hyaloclastites and three basalts (Table 1). The hyaloclastites are composed of poorly vesicular lime-green to golden brown plagioclase-phyric palagonite. Some contain a few lithic fragments $(1-2 \%)$ of plagioclase-phyric tachylite or basalt. The palagonitized glass contains both microphenocrysts and megaphenocrysts of plagioclase; the former are polysynthetically twinned laths of about $\mathrm{An}_{65}$ and some of the latter are Carlsbad-twinned and optically zoned. A few clinopyroxenes and a single dark brown smectite-replaced megacryst (pseudomorphed olivine?) were also observed, although plagioclase is by far the most abundant, easily recognizable phenocryst phase in the glass clasts.

The basalt clasts are variably vesicular, fine-grained, and hypocrystalline, and all are characterized by large plagioclase phenocrysts. They show a range from quenched plagioclase-rich textures to slightly coarser intersertal textures containing granular clinopyroxene and lath-like plagioclase. Parts of some clasts (e.g., samples 3 and 4) may exhibit a poorly developed flow orientation of plagioclase laths and microlites, some of the latter of which may be highly acicular and curved and may exhibit forked terminations. Between the plagioclase crystals is a dark brown fibrous material, much of which probably consists of poorly birefringent clinopyroxene crystallites. In the better-crystallized basalt clast (sample 7), the clinopyroxene is granular or is sometimes present as poorly developed quenched plumes. Small greenish smectite ovoids in these basalts may represent pseudomorphs after matrix olivine. Interstitial glass is invariably replaced by granular pale yellow-brown to brown palagonite or an opaque, oxidized smectite(?). Plagioclase phenocrysts are between 0.5 and $1.0 \mathrm{~mm}$ long (some larger crystals are up to $3 \mathrm{~mm}$ long) and generally replaced centrally or in specific zones by dark green pleochroic smectite. Circular vesicles $(0.2-3.0 \mathrm{~mm}$ diameter) are infilled by an inner thin rim of lime-green smectite and a core of coarse fibrous plates of strongly pleochroic bluish green celadonite.

In summary, the primary petrographic features indicate that all the clasts (with the possible exception of sample 1, Group A; see discussion following) are tholei- itic, with phenocryst assemblages dominated by plagioclase and lesser amounts of olivine and clinopyroxene. Only in one case (sample 7, Group C) has olivine been identified in the groundmass, although its presence elsewhere could be masked by alteration products.

\section{CHEMICAL CHARACTERISTICS AND RELATIONSHIPS}

Chemical and normative data for the nine clast samples are presented in Tables 2 and 3, respectively. All the clasts have basaltic compositions with moderate levels of incompatible elements, typical of tholeiites, together with low $\mathrm{Mg}$ numbers (49-63) relative to those of primary melts (68-75; Frey et al., 1978). In general, the chemistry of the clasts indicates that they are all of relatively well evolved compositions. As seen from their respective norms, all the clasts are quartz-normative tholeiites, except sample 1 (Group A), which is olivine-normative. This is the only clast to contain a reasonable proportion of identifiable olivine phenocrysts, and it is also chemically distinct from the other samples. In particular, the generally higher incompatible-element contents, high $\mathrm{Zr} / \mathrm{Y}$ and $\mathrm{Nb} / \mathrm{Y}$ ratios, and higher degree of light-REE to heavy-REE fractionation suggest that this clast may have transitional or alkali basalt affinities. This is consistent with the chemical analysis of pyroxene crystal debris in the same section as sample 1 (Section 58548-1), which also has alkaline compositions (Floyd, this volume; Viereck et al., this volume).

\section{Alteration Effects}

As already indicated, all the clasts have been altered to some degree, principally with the development of hydrous smectites and palagonite. This is reflected by moderate to high levels of water, whereas, the degree of oxidation $\left(\mathrm{Fe}_{2} \mathrm{O}_{3} / \mathrm{FeO}\right)$ and of carbonation $\left(\mathrm{CO}_{2}\right.$ content) are relatively low. Low-grade hydrous alteration can, however, cause variation in the contents of the more mobile elements (e.g., $\mathrm{K}, \mathrm{Rb}, \mathrm{Ba}, \mathrm{Sr}$ ) and disturb magmatic trends (e.g., Hart et al., 1974; Humphris and Thompson, 1978). Note in particular the highly variable $\mathrm{K} / \mathrm{Rb}$ ratio (Table 2) and the scatter of data for $\mathrm{K}_{2} \mathrm{O}, \mathrm{Rb}, \mathrm{Ba}$, and $\mathrm{Sr}$ plotted against a relatively stable element, $\mathrm{Zr}$ (Fig. 2). There is also a tendency for the hyaloclastites as a group to have higher $\mathrm{Rb}$ and $\mathrm{Ba}$ abundances than the basalts. This feature probably reflects the differential absorption of these elements by palagonitized glass relative to the more crystalline basalts (cf. Frey et al., 1974; Staudigel et al., 1979).

One other chemical effect results from the matrix zeolitization of sample 2 (Group B), which, because of the introduction of $\mathrm{Ca}$ (from the zeolite), has produced excess wollastonite (Wo) in the norm (Table 3). Zeolitization has not only enhanced the $\mathrm{CaO}$ and $\mathrm{Sr}$ contents (Fig. 2), but systematically dilutes other element abundances, although their relative proportions remain the same.

\section{Relationships between Samples}

The three petrographic groups are chemically distinguished by their respective $\mathrm{Zr} / \mathrm{Y}$ ratios and chondritenormalized REE fractionation patterns (Figs. 3 and 4). 
Table 2. Chemical data for clasts extracted from Site 585 debris flows (samples 1-9) and averages for Hawaiian and Icelandic tholeiites compiled from the literature (samples 10 and 11, respectively).

\begin{tabular}{|c|c|c|c|c|c|c|c|c|c|c|c|}
\hline $\begin{array}{l}\text { Sample number }{ }^{\mathrm{a}} \\
\text { Petrographic group }\end{array}$ & $\begin{array}{l}1 \\
\mathrm{~A}\end{array}$ & $\begin{array}{l}2 \\
\text { B }\end{array}$ & $\stackrel{3}{\mathrm{C}}$ & $\begin{array}{l}4 \\
\mathrm{C}\end{array}$ & $\begin{array}{l}5 \\
\text { B }\end{array}$ & $\begin{array}{l}6 \\
\text { B }\end{array}$ & $\begin{array}{l}7 \\
\mathrm{C}\end{array}$ & $\begin{array}{l}8 \\
\mathrm{C}\end{array}$ & $\begin{array}{l}9 \\
\mathrm{C}\end{array}$ & 10 & 11 \\
\hline \multicolumn{12}{|l|}{ Major elements (wt.\%) } \\
\hline $\mathrm{SiO}_{2}$ & 47.43 & 50.43 & 49.82 & 50.48 & 50.53 & 49.73 & 48.55 & 47.74 & 47.56 & 49.23 & 49.01 \\
\hline $\mathrm{TiO}_{2}^{2}$ & 2.61 & 1.33 & 2.18 & 2.12 & 1.72 & 1.75 & 2.29 & 1.84 & 1.79 & 2.50 & 3.02 \\
\hline $\mathrm{Al}_{2} \mathrm{O}_{3}$ & 14.57 & 8.83 & 14.88 & 14.31 & 14.91 & 14.64 & 16.74 & 14.73 & 15.04 & 13.93 & 14.04 \\
\hline $\mathrm{Fe}_{2} \mathrm{O}_{3}$ & 5.77 & 3.47 & 5.03 & 4.60 & 3.78 & 4.88 & 5.93 & 7.22 & 7.52 & 3.09 & 6.43 \\
\hline $\mathrm{FeO}$ & 4.84 & 4.10 & 5.05 & 5.06 & 5.88 & 6.13 & 5.15 & 3.77 & 3.32 & 8.52 & 7.84 \\
\hline $\mathrm{MnO}$ & 0.56 & 0.11 & 0.19 & 0.14 & 0.25 & 0.28 & 0.17 & 0.17 & 0.17 & 0.16 & 0.24 \\
\hline $\mathrm{MgO}$ & 5.82 & 5.58 & 7.55 & 7.79 & 6.07 & 7.30 & 5.08 & 7.58 & 7.37 & 8.40 & 5.46 \\
\hline $\mathrm{CaO}$ & 12.08 & 16.80 & 11.29 & 10.93 & 10.84 & 10.27 & 11.82 & 7.75 & 7.19 & 10.35 & 9.82 \\
\hline $\mathrm{Na}_{2} \mathrm{O}$ & 2.42 & 1.71 & 2.37 & 2.48 & 2.64 & 2.41 & 2.31 & 2.26 & 2.38 & 2.16 & 2.78 \\
\hline $\mathrm{K}_{2} \mathrm{O}$ & 0.81 & 0.29 & 0.47 & 0.94 & 0.59 & 0.29 & 0.31 & 0.34 & 0.30 & 0.38 & 0.48 \\
\hline $\mathrm{P}_{2} \mathrm{O}_{5}$ & 0.28 & 0.16 & 0.29 & 0.29 & 0.19 & 0.19 & 0.24 & 0.21 & 0.22 & 0.26 & 0.39 \\
\hline $\mathrm{H}_{2} \mathrm{O}^{+}$ & 2.29 & 6.59 & 1.51 & 1.57 & 1.85 & 1.62 & 1.76 & 5.47 & 6.26 & 0.61 & 1.52 \\
\hline $\mathrm{CO}_{2}$ & 0.52 & 0.61 & 0.37 & 0.63 & 0.40 & 0.40 & 0.77 & 0.60 & 0.60 & 0.10 & 0.12 \\
\hline Specific gravity & 2.72 & 2.44 & 2.73 & 2.55 & 2.72 & 2.71 & 2.60 & 2.18 & 2.12 & - & - \\
\hline
\end{tabular}

Trace elements (ppm)

$\begin{array}{lc}\mathrm{Ba} & 545 \\ \mathrm{Ce} & 30 \\ \mathrm{Cr} & 159 \\ \mathrm{Hf} & 3.1 \\ \mathrm{La} & 16 \\ \mathrm{Nb} & 20 \\ \mathrm{Nd} & 25 \\ \mathrm{Ni} & 89 \\ \mathrm{Rb} & 14 \\ \mathrm{Sc} & 36 \\ \mathrm{Sr} & 473 \\ \mathrm{Ta} & 1.56 \\ \mathrm{Th} & 2.00 \\ \mathrm{U} & 0.85 \\ \mathrm{Y} & 18 \\ \mathrm{Zr} & 128\end{array}$

$\begin{array}{ccc}56 & 137 & 117 \\ 13 & 31 & 29 \\ 169 & 203 & 188 \\ 1.8 & 3.4 & 3.3 \\ 6 & 11 & 13 \\ 8 & 10 & 11 \\ 6 & 17 & 20 \\ 80 & 100 & 108 \\ 9 & 8 & 13 \\ 27 & 25 & 24 \\ 1400 & 694 & 501 \\ 0.50 & 1.29 & 1.12 \\ 0.61 & 1.19 & 1.14 \\ 0.20 & 0.34 & 0.36 \\ 19 & 28 & 27 \\ 70 & 125 & 127\end{array}$

$\begin{array}{cc}47 & 40 \\ 22 & 20 \\ 230 & 358 \\ 2.1 & 2.0 \\ 8 & 10 \\ 11 & 9 \\ 13 & 12 \\ 78 & 299 \\ 8 & 4 \\ 31 & 30 \\ 450 & 351 \\ 0.60 & 0.53 \\ 0.90 & 0.68 \\ 0.25 & 0.21 \\ 25 & 23 \\ 88 & 80\end{array}$

38
26
240
2.6
12
12
14
98
6
33
447
0.79
0.81
0.23
21
95

225
23
360
2.4
8
10
17
183
10
31
521
0.77
0.91
0.27
19
89

$\begin{array}{ccc}234 & 202 & 96 \\ 24 & 31 & 42 \\ 343 & 269 & 46 \\ 2.4 & 3.9 & 4.8 \\ 8 & 11 & 19 \\ 10 & 14 & 29 \\ 15 & 22 & 25 \\ 160 & 126 & 32 \\ 9 & 8 & 8 \\ 29 & 31 & 39 \\ 457 & 350 & 269 \\ 0.79 & 0.90 & 1.14 \\ 0.93 & 0.68 & 1.45 \\ 0.28 & - & - \\ 20 & 26 & 44 \\ 88 & 161 & 213\end{array}$

REE (ppm)

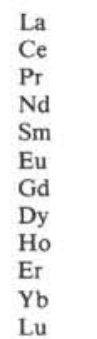

Ratios

$\begin{array}{rrr}15.89 & 6.49 & 12 . \\ 34.21 & 14.85 & 28.94 \\ 4.42 & 2.02 & 3.98 \\ 19.67 & 9.92 & 18.41 \\ 5.22 & 2.73 & 4.68 \\ 1.92 & 1.05 & 1.73 \\ 4.71 & 2.86 & 4.66 \\ 4.13 & 2.68 & 4.07 \\ 0.76 & 0.52 & 0.76 \\ 2.04 & 1.42 & 2.06 \\ 1.60 & 1.08 & 1.57 \\ 0.25 & 0.16 & 0.24\end{array}$

$\begin{array}{rr}12.15 & 12.1 \\ 28.94 & 27.43 \\ 3.98 & 3.89 \\ 18.41 & 18.00 \\ 4.68 & 4.58 \\ 1.73 & 1.68 \\ 4.66 & 4.44 \\ 4.07 & 3.94 \\ 0.76 & 0.74 \\ 2.06 & 2.02 \\ 1.57 & 1.5 \\ 0.24 & 0.24\end{array}$
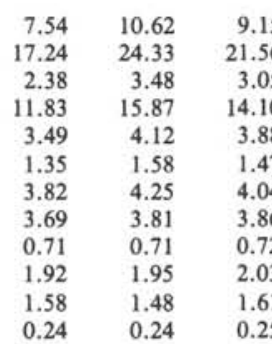

$\mathrm{Mg}$ number
$\mathrm{K} / \mathrm{Rb}$
$\mathrm{Zr} / \mathrm{Y}$
$\mathrm{Ce} / \mathrm{Y}$
$\mathrm{La} / \mathrm{Sm}$
$\mathrm{Zr} / \mathrm{Nb}$
$\mathrm{La} / \mathrm{Nb}$
$\mathrm{P}_{2} \mathrm{O}_{5} / \mathrm{Ce}$

$\begin{array}{cc}53.9 & 61.0 \\ 480 & 267 \\ 7.1 & 3.7 \\ 1.7 & 0.7 \\ 3.0 & 2.4 \\ 6.4 & 8.8 \\ 0.8 & 0.8 \\ 93 & 123\end{array}$

61.5
488
4.5
1.3
2.6
12.5
1.1
94

$\begin{array}{cc}63.1 & 56.9 \\ 600 & 612 \\ 4.7 & 3.5 \\ 1.1 & 0.9 \\ 2.7 & 2.4 \\ 11.5 & 8.0 \\ 1.2 & 0.7 \\ 100 & 86\end{array}$

$\begin{array}{cc}58.4 & 49 \\ 602 & 429 \\ 3.5 & \\ 0.9 & \\ 2.2 & \\ 8.9 & \\ 1.1 & \\ 95 & 92.6\end{array}$

$\begin{array}{cc}49.5 & 59 . \\ 429 & 28 \\ 4.5 & \\ 1.2 & \\ 2.6 & \\ 7.9 & \\ 1.0 & \\ 92 & 91\end{array}$

$\begin{array}{cccc}59.9 & 59.6 & 60.2 & 44.7 \\ 282 & 277 & 374 & 228 \\ 4.7 & 4.4 & 6.2 & 4.8 \\ 1.2 & 1.2 & 1.2 & 0.9 \\ 2.4 & 2.5 & 2.2 & 2.6 \\ 8.9 & 8.8 & 11.5 & 7.3 \\ 0.8 & 0.8 & 0.8 & 0.7 \\ 91 & 92 & 84 & 93\end{array}$

Note: Dash indicates no data.

${ }^{a}$ Corresponding DSDP sample numbers are given in Table 1.

The Group A sample, with alkaline affinities, has a $\mathrm{Zr} / \mathrm{Y}$ ratio of 7.1, and is clearly distinct from the Group B and Group $\mathrm{C}$ tholeiities, which have ratios of 3.6 and 4.5 , respectively. These latter values are relatively close, but the difference between them is greater than the analytical error (about \pm 0.2 for each ratio). The samples in each group show variable hydration, although the degree of alteration has not affected the overall group $\mathrm{Zr}$ /
Y ratio. Zeolitization of sample 2 has, however, reduced the absolute abundances of $\mathrm{Zr}$ and $\mathrm{Y}$, but not their relative proportions, which are characterisitc of Group B.

Constancy of the $\mathrm{Zr} / \mathrm{Y}$ ratio implies that the samples within each petrographic-chemical group could be related by the fractionation of major phases-such as olivine, plagioclase, and (to a lesser extent) clinopyroxene-that exclude $\mathrm{Zr}$ and $\mathrm{Y}$ from their structures. Mafic 
Table 3. Normative composition ${ }^{\mathrm{a}}$ of basaltic clasts, Site 585, East Mariana Basin.

\begin{tabular}{|c|c|c|c|c|c|c|c|c|c|c|c|}
\hline $\begin{array}{c}\text { Sample } \\
\text { number }\end{array}$ & Qz & Or & $\mathrm{Ab}$ & An & Di & Hy & Ol & Wo & Mt & Il & Ap \\
\hline 1 & - & 4.98 & 21.31 & 27.58 & 24.22 & 10.12 & 3.96 & - & 2.00 & 5.16 & 0.69 \\
\hline 2 & 7.30 & 1.87 & 15.77 & 16.96 & 50.91 & - & - & 2.54 & 1.51 & 2.75 & 0.41 \\
\hline 3 & 0.54 & 2.83 & 20.41 & 29.08 & 19.21 & 21.18 & - & - & 1.87 & 4.21 & 0.70 \\
\hline 4 & 0.13 & 5.67 & 21.41 & 25.65 & 19.23 & 21.32 & - & - & 1.80 & 4.11 & 0.70 \\
\hline 5 & 1.99 & 3.61 & 23.12 & 28.03 & 19.45 & 18.13 & - & - & 1.84 & 3.38 & 0.47 \\
\hline 6 & 1.31 & 1.77 & 21.02 & 29.14 & 15.97 & 24.83 & - & - & 2.07 & 3.43 & 0.46 \\
\hline 7 & 2.09 & 1.89 & 20.12 & 35.40 & 15.16 & 18.24 & - & - & 2.07 & 4.48 & 0.59 \\
\hline 8 & 2.95 & 2.18 & 20.73 & 31.48 & 3.75 & 32.47 & - & - & 2.13 & 3.79 & 0.54 \\
\hline 9 & 3.19 & 1.94 & 22.02 & 32.22 & 0.87 & 33.40 & - & - & 2.11 & 3.72 & 0.57 \\
\hline
\end{tabular}

a Calculated on anhydrous, carbonate-free basis and an $\mathrm{Fe}_{2} \mathrm{O}_{3} / \mathrm{FeO}=0.15$.

${ }^{b}$ Corresponding DSDP sample numbers are given in Table 1 .
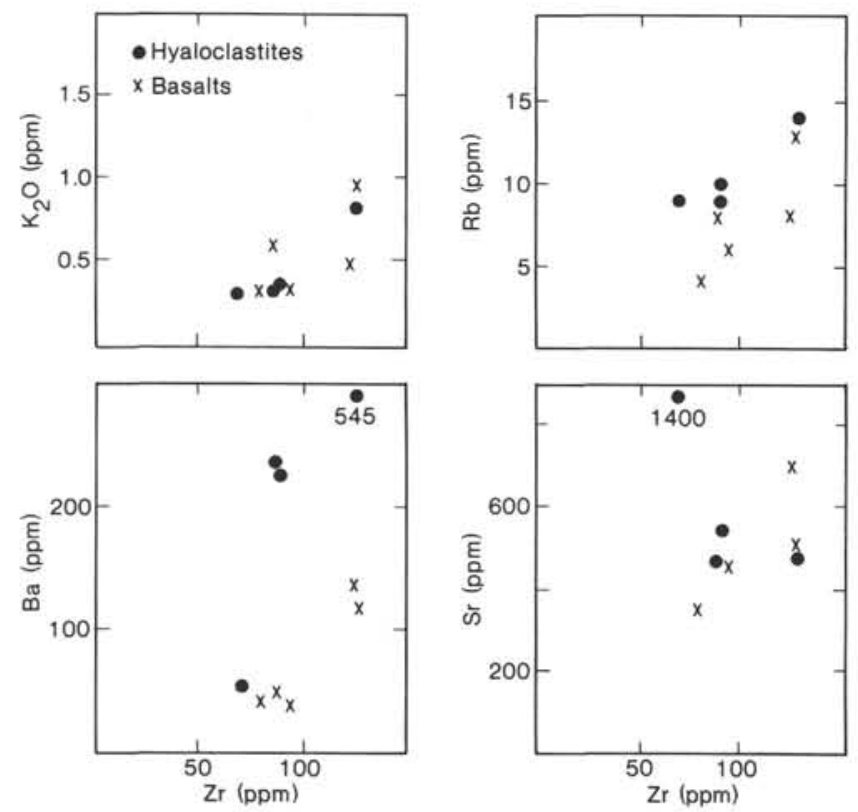

Figure 2. Distribution of $\mathrm{K}_{2} \mathrm{O}, \mathrm{Rb}, \mathrm{Ba}$, and $\mathrm{Sr}$ (all of which are considered mobile under low-grade alteration) relative to a stable element, $\mathrm{Zr}$, in hyaloclastites relative to basalt clasts.

fractionation within Groups B and C is indicated by variation of $\mathrm{Ni}, \mathrm{Cr}$, and $\mathrm{Sc}$ contents, which generally decrease as incompatiable-element contents increase (Table 2). As seen in Figure 3, decreasing Ni indicates olivine fractionation, whereas decreasing $\mathrm{Cr}$ (and $\mathrm{Sc}$ ) implies clinopyroxene involvement during crystallization. However, fractional crystallization of clinopyroxene can cause minor fractionation of REE patterns (as seen in Fig. 4), with relative light-REE enrichment but similar heavyREE normalized contents. This latter feature is also illustrated by a progressive increase in $\mathrm{Ce} / \mathrm{Yb}$ ratio as $\mathrm{Cr}$ content falls for both Groups B and C (Fig. 3). The chemical relationships of Group $\mathrm{C}$ samples imply the operation of both olivine and clinopyroxene fractionation, although neither mineral is observed in phenocryst phases of the extracted clasts. On the other hand, plagioclase is a dominant phenocryst phase in all groups, but because of the mobility of $\mathrm{Sr}$ (hosted by calcic plagioclase) its influence during fractionation cannot be readily demonstrated. However, the small positive Eu anomalies seen in the normalized REE patterns (Fig. 4; Eu/
Eu* ranges from 1.1 to 1.7$)$ probably reflect the presence of accumulated plagioclase phenocrysts. Sample 3 (Group C), with the highest $\mathrm{Eu} / \mathrm{Eu}^{*}$ ratio (1.69), also has the highest $\mathrm{Sr}$ content (694 ppm) of all the unzeolitized samples.

Good covariance is observed between all the samples in the plot of incompatible elements against $\mathrm{Zr}$, which can be used as a stable fractionation index (Fig. 5). The visual best-fit lines have been drawn through zero, and accommodate the majority of the data points in each plot. The two high-Zr samples of Group C, however, fall off the linear correlation for $\mathrm{TiO}_{2}$ and $\mathrm{Nb}$, and indicate that titanomagnetite fractionation was also involved in the evolution of this group.

On the basis of observed phenocryst phases and/or chemical relationships, within-group variation can generally be accounted for by variable olivine, clinopyroxene, and plagioclase fractionation in Groups B and C, together with minor titanomagnetite fractionation in Group C. Fractionation of the major phases would systematically enhance most incompatible-element abundances, including the REE, and maintain constant ratios relative to $\mathrm{Zr}$ (Fig. 5).

\section{Relationships between Groups}

Each petrographic group can be distinguished by its specific $\mathrm{Zr} / \mathrm{Y}$ ratio, and chemically represents three separate fractionated suites. As already indicated, crystal fractionation processes will cause variations in incompatible-element abundances, but little or no change in ratios of more- to less-incompatible elements. Variations in such ratios, like $\mathrm{Zr} / \mathrm{Y}$, can be considered in terms of equilibrium partial-melting processes of a homogeneous mantle source (Pearce and Norry, 1979; Bougault et al., 1979; Wood et al., 1979). Thus, the three groups with different $\mathrm{Zr} / \mathrm{Y}$ ratios identified in this study could be related by variable partial melting of a common source. Variation in the $\mathrm{Zr} / \mathrm{Y}$ ratio could be achieved if garnet was present as a refactory phase, because it would preferentially retain $\mathrm{Y}$ relative to $\mathrm{Zr}$ for low degrees of melting. Such a relationship between the groups is suggested, in part, by the similar $\mathrm{Mg}$ numbers and $\mathrm{Cr}$ and $\mathrm{Sc}$ contents (Fig. 3, Table 2)-which would not change markedly with variable, but moderate, degrees of meltingof the least-evolved compositions of Groups B and C (samples 6 and 8 respectively). Variable partial melting 

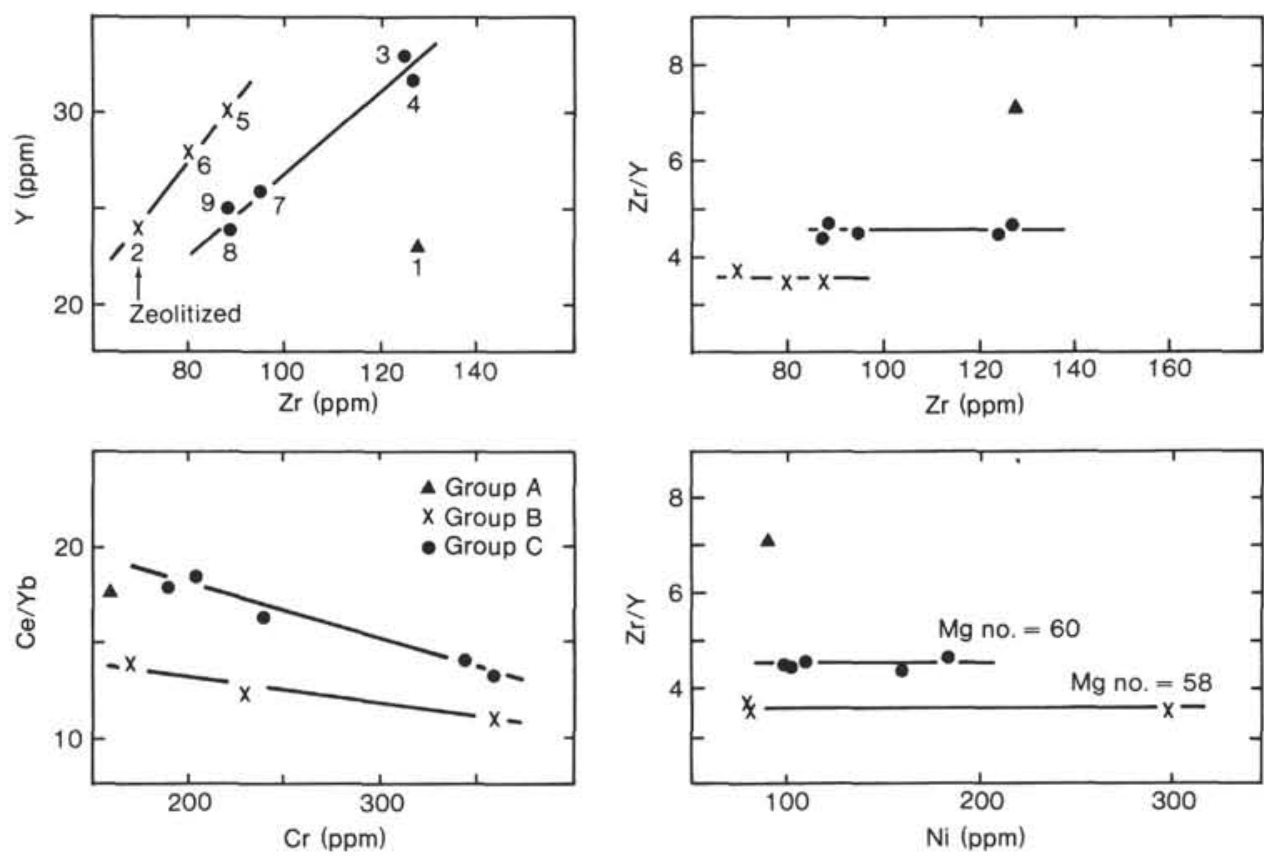

Figure 3. Variation of $\mathrm{Zr} / \mathrm{Y}$ and $\mathrm{Ce} / \mathrm{Yb}$ ratios and compatible elements $\mathrm{Cr}$ and $\mathrm{Ni}$ in different clast groups. Samples numbered as in Table 1.
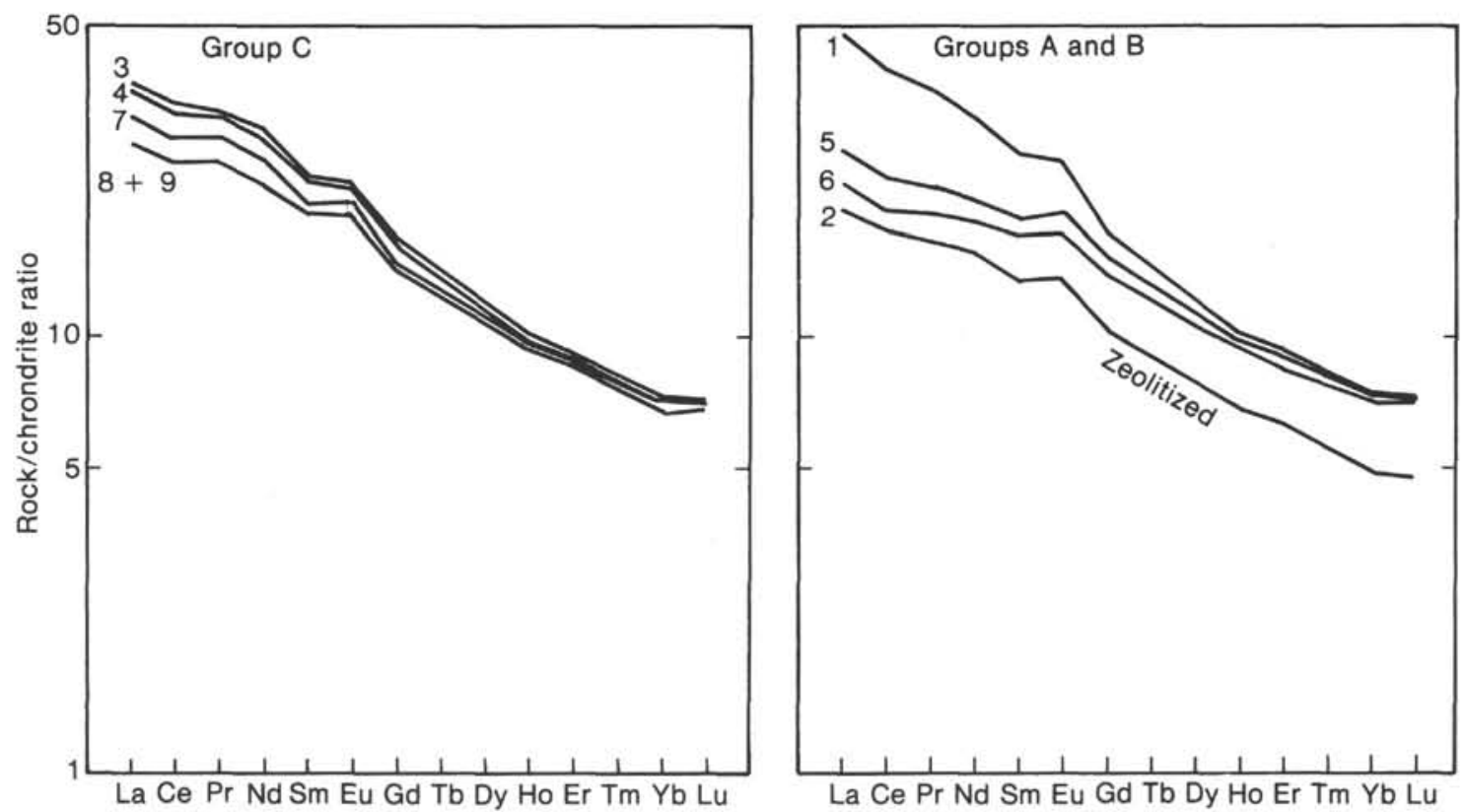

Figure 4. Chondrite-normalized REE patterns in different clast groups. Samples numbered as in Table 1.

would also fractionate the REE, especially if garnet or pyroxene was in the source, and would account for the small differences in $\mathrm{Ce} / \mathrm{Yb}$ ratio between the least-evolved compositions of Groups B and C (Fig. 3). The progressive increase in the ratio within each group is caused, however, by clinopyroxene fractionation, which accommodates $\mathrm{Yb}$ relative to $\mathrm{Ce}$. The differences between the actual abundances of incompatible elements of the two least-evolved compositions also reflect variable partial melting. Group A could be the product of a relatively low degree of melting compared with Groups B and C, which, as suggested by the similarity of their $\mathrm{Zr} / \mathrm{Y}$ and $\mathrm{Ce} / \mathrm{Yb}$ ratios, were probably produced by higher, more closely related degrees of melting.

Ratios of highly incompatible elements, such as $\mathrm{La}$ / $\mathrm{Nb}$ and $\mathrm{P}_{2} \mathrm{O}_{5} / \mathrm{Ce}$, reflect the composition of the source undergoing melting; significant variations in these ratios imply source heterogeneity (Erlank and Kable, 1976; Wood et al., 1979; Bougault et al., 1979), or possibly magma-mixing from "end member" sources (Flower, 1981; Frey and Clague, 1983). Although these ratios do vary in the samples studied here (Table 2), the variation 

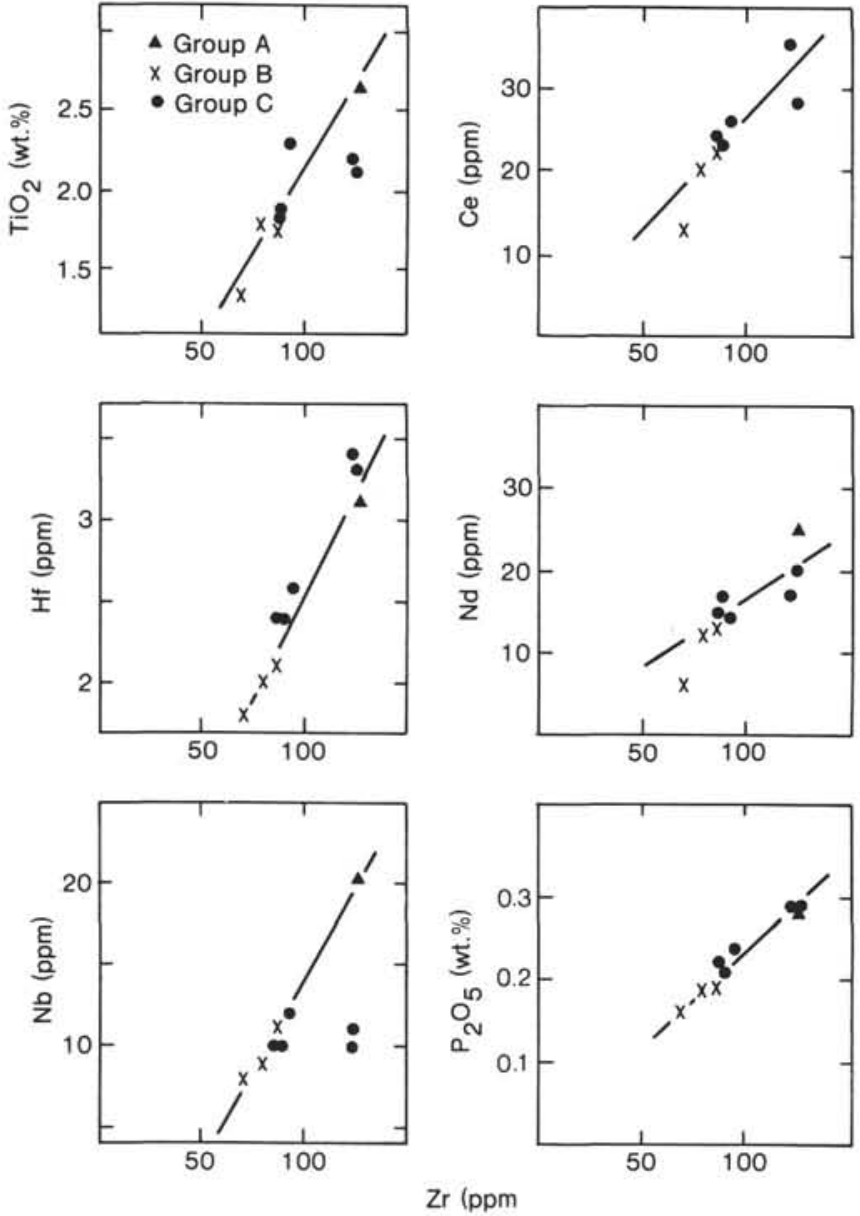

Figure 5. Distribution of various incompatible elements relative to $\mathrm{Zr}$ in different clast groups.

is very minor and can be largely accounted for by analytical error rather than source variation. Similarly, the good correlation between the more incompatible elements and $\mathrm{Zr}$ (Fig. 5), for all samples, irrespective of assigned group or magma type, again suggests a common source.

As exhibited by the normalized patterns in Fig. 6, the progressive enhancement of the incompatible elements indicates that the source was of an enriched composition relative to that of a depleted MORB-type source. The enrichment of such elements reflects the source and is typical of many intraplate basaltic provinces (Thompson et al., 1983), although in this instance the enrichment cannot be the result of sialic contamination of MORB-type magmas, since the Pacific Plate was clearly an oceanic environment during the Cretaceous. Note that Groups B and C remain separate in Fig. 6 until the most incompatible elements are reached, and then some overlap occurs between them. This probably reflects the mobility of these particular elements during low-grade alteration.

In summary, the clasts sampled could be the products of variable partial melting of a homogeneous, enriched mantle source, together with subsequent low-pressure fractional crystallization.

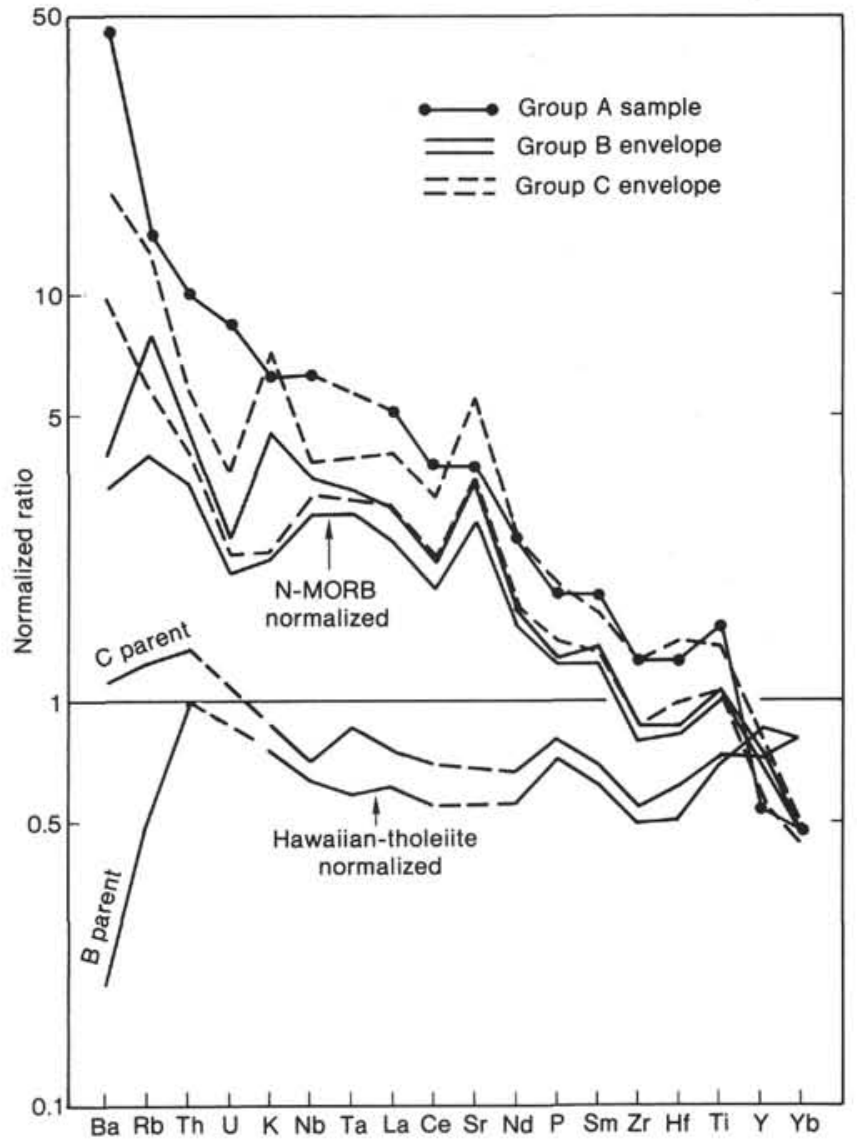

Figure 6. Multi-element diagram for the different clast groups-normalized relative to N-MORB and least-evolved compositions for groups $\mathrm{B}$ and $\mathrm{C}$ normalized relative to an average Hawaiian tholeiite. Normalization values for average N-MORB and Hawaiian tholeiite given in Floyd (this volume).

\section{GEOCHEMICAL COMPARISONS}

Because the extracted clasts form part of a debris flow derived from local seamounts, they represent intraplate volcanism that was probably wholly submarine (Floyd, this volume). On chemical diagrams that discriminate among tectonic environments (e.g., Pearce and Cann, 1973; Wood, 1980; Mullen, 1983), they are also designated as intraplate, as might be expected (Fig. 7). They are clearly distinguishable from MORB by their absolute abundances and their ratios of incompatible elements(Fig. 6). In common with plume-related oceanic basalts, this implies that their source is similarly enriched, relative to a MORB source. Not all oceanic island/ seamount basalts, however, may be generated above longlived, fixed plumes sampling deep mantle (pristine?) sources. If the basalts sampled here are representative of non-hot-spot volcanism, their overall chemical similarity to typical hot-spot oceanic-island basalts implies generation from a broadly similar intraplate source.

At present, data are too limited for detailed comparisons between hot-spot- and non-hot-spot-generated magmas, although the tholeiitic clasts do differ slightly from typical Hawaiian tholeiites. As seen in Figure 6, normal- 

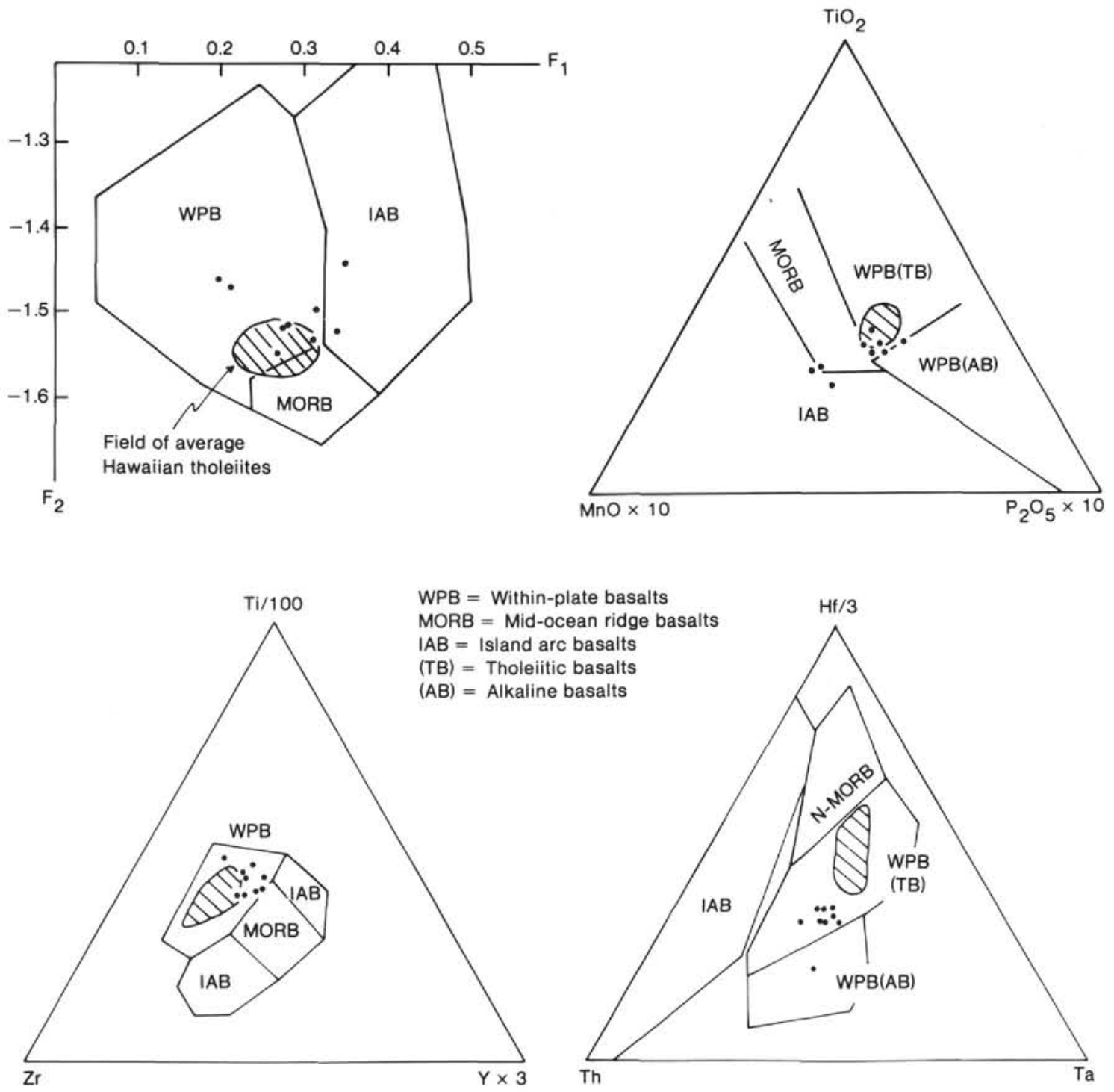

Figure 7. Chemical discrimination of tectonic environment for Site 585 clasts using various diagrams after Pearce and Cann (1973), Pearce (1976), Wood (1980), and Mullen (1983). Hawaiian tholeiite field encloses averaged data from Leeman et al. (1980) and is plotted for comparison. Only those plots employing the more immobile trace elements succeed in designating an intraplate environment for all the analyzed samples.

ization of the least-evolved compositions for Groups B and $\mathrm{C}$, relative to a Hawaiian average, shows the nonhot-spot lavas to be relatively depleted in the least incompatible elements or, in particular, those with high field strength (charge/radius ratio). Similarly, chondritenormalized REE patterns show that all the REE are depleted, compared with typical tholeiites from Hawaii and Loihi Seamount (Fig. 8). These variations may not be very significant, and may indicate only minor differences in the degree of melting of essentially similar source compositions. They differ considerably, however, from tholeiitic basalts dredged from seamounts near the East Pacific Rise (ERP), which predominantly show depleted REE patterns (Batiza, 1980) and have been derived from a source different from typical ocean-island magmas.

\section{CONCLUSIONS}

Nine basalt and hyaloclastite clasts extracted from volcaniclastic debris flows derived from the flanks of sea- mounts are predominantly quartz-normative tholeiites; one has an olivine-normative alkalic composition. On the basis of petrographic features and chemical relationships, the clasts are classified into three groups exhibiting the following phenocryst assemblages: plagioclaseclinopyroxene-olivine (Group A, 1 sample), plagioclaseolivine (Group B, 3 samples), and plagioclase (Group C, 5 samples). The groups are chemically distinguishable by their absolute abundances of incompatible elements, their ratios of most/least incompatible elements $(\mathrm{Zr} / \mathrm{Y})$, and their normalized REE patterns and ratios $(\mathrm{Ce} / \mathrm{Yb})$. Compatible-element distributions within each group reflect variable low-pressure olivine and clinopyroxene fractionation, even when these phases are not readily observable as phenocrysts. The groups could be related by the variable partial melting of a homogeneous enriched source. Normalized incompatible-element diagrams demonstrate that the source is enriched relative to a MORB source, and in respect to the highly incompatible ele- 


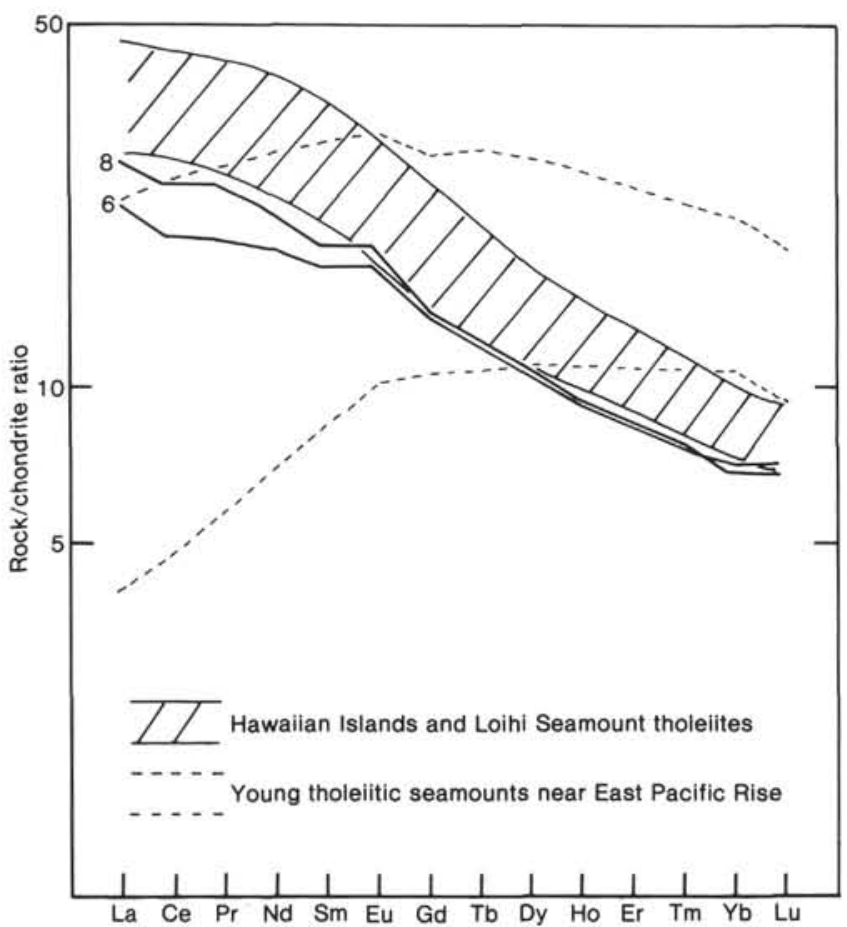

Figure 8. Chondrite-normalized REE comparison of least-evolved compositions in groups $\mathrm{B}$ and $\mathrm{C}$ with average Hawaiian tholeites (Leeman et al., 1980); Loihi Seamount (Frey and Clague, 1983); and young seamount tholeiites near the East Pacific Rise (Batiza, 1980).

ments is similar to hot-spot-generated oceanic island tholeiites (e.g., Hawaii). Minor chemical differences relative to typical enriched hot-spot magmas are apparent, however, in that the basalts studied here are depleted in many high-field-strength elements.

\section{ACKNOWLEDGMENTS}

For the analytical work thanks are due D. Emley and M. Aiken, University of Keele, U.K. (major elements and most trace elements by XRF); Dr. G. Gilmore, Universities Research Reactor, Risley (Hf, Ta, Th, U); and Dr. N. Walsh, Kings College, London (REE). Comments by Dr. P. Fryers and Dr. C. Evans are acknowledged.

\section{REFERENCES}

Batiza, R., 1980. Origin and petrology of young oceanic central volcanoes: Are most tholeiitic rather than alkalic? Geology, 8:477-482.

Bougault, H., Cambon, P., Corre, T., Joron, J. L., and Treuil, M., 1979. Evidence for variability of magmatic processes and upper mantle heterogeneity in the axial region of the Mid-Atlantic Ridge near $22^{\circ} \mathrm{N}$ and $36^{\circ} \mathrm{N}$. Tectonophysics, 55:11-34.

Duffield, J., and Gilmore, G. R., 1979. An optimum method for the determination of rare earth elements by neutron activation analysis. J. Radioanal. Chem., 48:135-145.

Erlank, A. J., and Kable, E. J. D., 1976. The significance of incompatible elements in Mid-Atlantic Ridge basalts from $45^{\circ} \mathrm{N}$ with particular reference to $\mathrm{Zr} / \mathrm{Nb}$. Contrib. Mineral. Petrol., 54:281-291.

Flower, M. F. J., 1981. Binary mixing in ocean-ridge spreading segments. Nature (London), 292:45-47.

Frey, F. A., Bryan, W. B., and Thompson, G., 1974. Atlantic Ocean floor: geochemistry and petrology of basalts from Legs 2 and 3 of the Deep Sea Drilling Project. J. Geophys. Res., 79:5507-5527.
Frey, F. A., and Clague, D. A., 1983. Geochemistry of diverse basalt types from Loihi Seamount, Hawaii: Petrogenetic implications. Earth Planet. Sci. Lett., 66:337-355.

Frey, F. A., Green, D. H., and Roy, S. D., 1978. Integrated models of basalt petrogenesis: A study of quartz tholeiites to olivine melilites from southeastern Australia utilizing geochemical and experimental petrological data. J. Petrol., 19:463-513.

Haggerty, J. A., Schlanger, S. O., and Premoli Silva, I., 1982. Late Cretaceous and Eocene volcanism in the southern Line Islands and implications for hotspot theory. Geology, 10:433-437.

Hart, S. R., Erlank, A. J., and Kable, E. J. D., 1974. Sea floor basalt alteration: Some chemical and $\mathrm{Sr}$ isotopic effects. Contrib. Mineral. Petrol., 44:219-230.

Humphris, S. E., and Thompson, G., 1978. Hydrothermal alteration of oceanic basalts by seawater. Geochim. Cosmochim. Acta, 42: $107-126$.

Larson, R. L., and Schlanger, S. O., 1981. Geological evolution of the Nauru Basin and regional implications. In Larson, R. L., Schlanger, S. O., et al., Init. Repts. DSDP, 61: Washington (U.S. Govt. Printing Office), 841-862.

Leeman, W. P., Budahn, J. R., Gerlach, D. C., Smith, D. R., and Powell, B. N., 1980. Origin of Hawaiian tholeiites: Trace element constraints. Am. J. Sci., 280A:794-819.

Mullen, E. D., 1983. $\mathrm{MnO} / \mathrm{TiO}_{2} / \mathrm{P}_{2} \mathrm{O}_{5}$ : A minor element discriminant for basaltic rocks of oceanic environments and its implications for petrogenesis. Earth Planet. Sci. Lett., 62:53-62.

Pearce, J. A., 1976. Statistical analysis of major element patterns in basalts. J. Petrol., 17:15-43.

Pearce, J. A., and Cann, J. R., 1973. Tectonic setting of basic volcanic rocks determined using trace element analyses. Earth Planet. Sci. Lett., 19:290-300.

Pearce, J. A., and Norry, M. J., 1979. Petrogenetic implications of Ti, $\mathrm{Zr}, \mathrm{Y}$ and $\mathrm{Nb}$ variations in volcanic rocks. Contrib. Mineral. Petrol., 69:33-47.

Schlanger, S. O., and Premoli Silva, I., 1981. Tectonic, volcanic and paleogeographic implications of redeposited reef faunas of Late Cretaceous and Tertiary age from the Nauru Basin and the Line Islands. In Larson, R. L., Schlanger, S. O., et al., Init. Repts. DSDP, 61: Washington (U.S. Govt. Printing Office), 817-827.

Staudigel, H., Bryan, W. B., and Thompson, G., 1979. Chemical variation in glass-whole rock pairs from individual cooling units in Holes 417D and 418A. In Donnelly, T., Francheteau, J., Bryan, W., Robinson, P., FLower, M., Salisbury, M., et al., Init. Repts. DSDP , 51, 52, 53, Pt. 2: Washington (U.S. Govt. Printing Office) 977-986.

Thompson, R. N., Morrison, M. A., Dickin, A. P., and Hendry, G. D., 1983. Continental flood basalts...arachnids rule OK? In Hawkesworth, C. J., and Norry, M. J. (Eds.), Continental Basalts and Mantle Xenoliths: Nantwich (Shiva Publishing Ltd., U.K.), pp. 158-185.

Walsh, J. N., Buckley, F., and Barker, J., 1981. The simultaneous determination of the rare earth elements in rock using inductively coupled plasma source spectrometry. Chem. Geol., 33:141-153.

Winterer, E. L., 1973. Regional problems. In Winterer, E. L., Ewing, J. I., et al., Init. Repts. DSDP, 17: Washington (U.S. Govt. Printing Office), 911-922.

Wood, D. A., 1980. The application of a Th-Hf-Ta diagram to problems of tectonomagmatic classification and to establishing the nature of crustal contamination of basaltic lavas of the British Tertiary Volcanic Province. Earth Planet. Sci. Lett., 50:11-30.

Wood, D. A., Tarney, J., Varet, J., Saunders, A. D., Bougault, H., et al., 1979. Geochemistry of basalts drilled in the North Atlantic by IPOD Leg 49: Implications for mantle heterogeneity. Earth Planet. Sci. Lett., 42:77-97.

Date of Initial Receipt: 19 April 1984

Date of Acceptance: 12 March 1985 

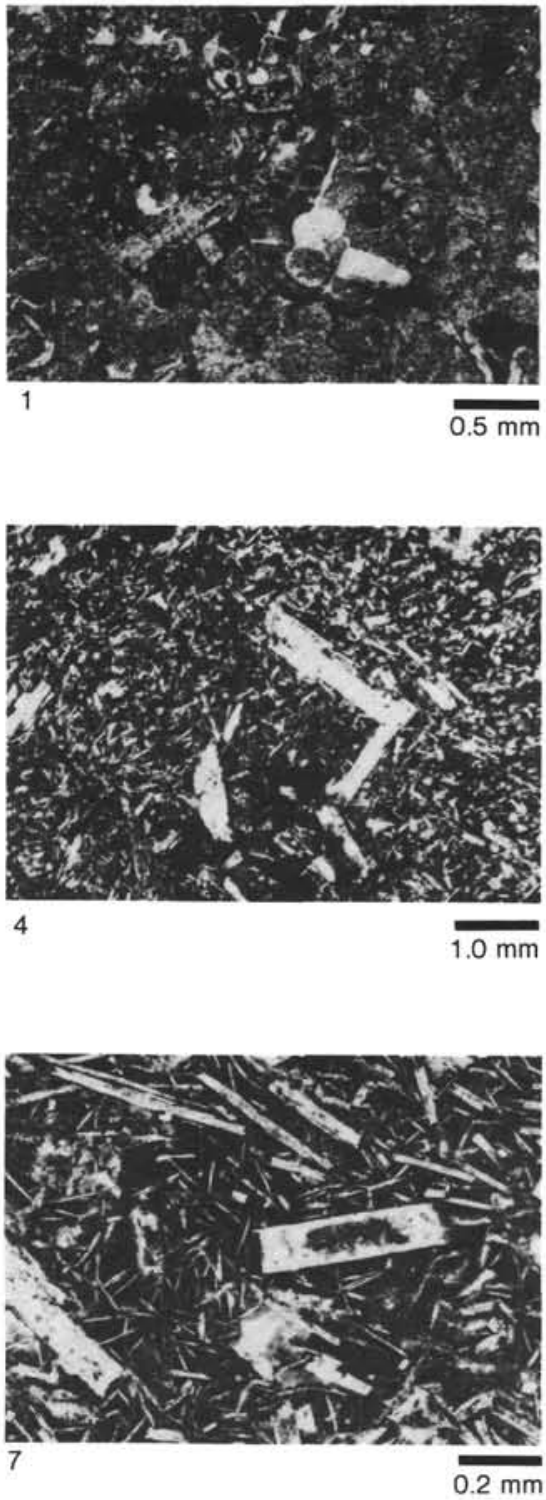
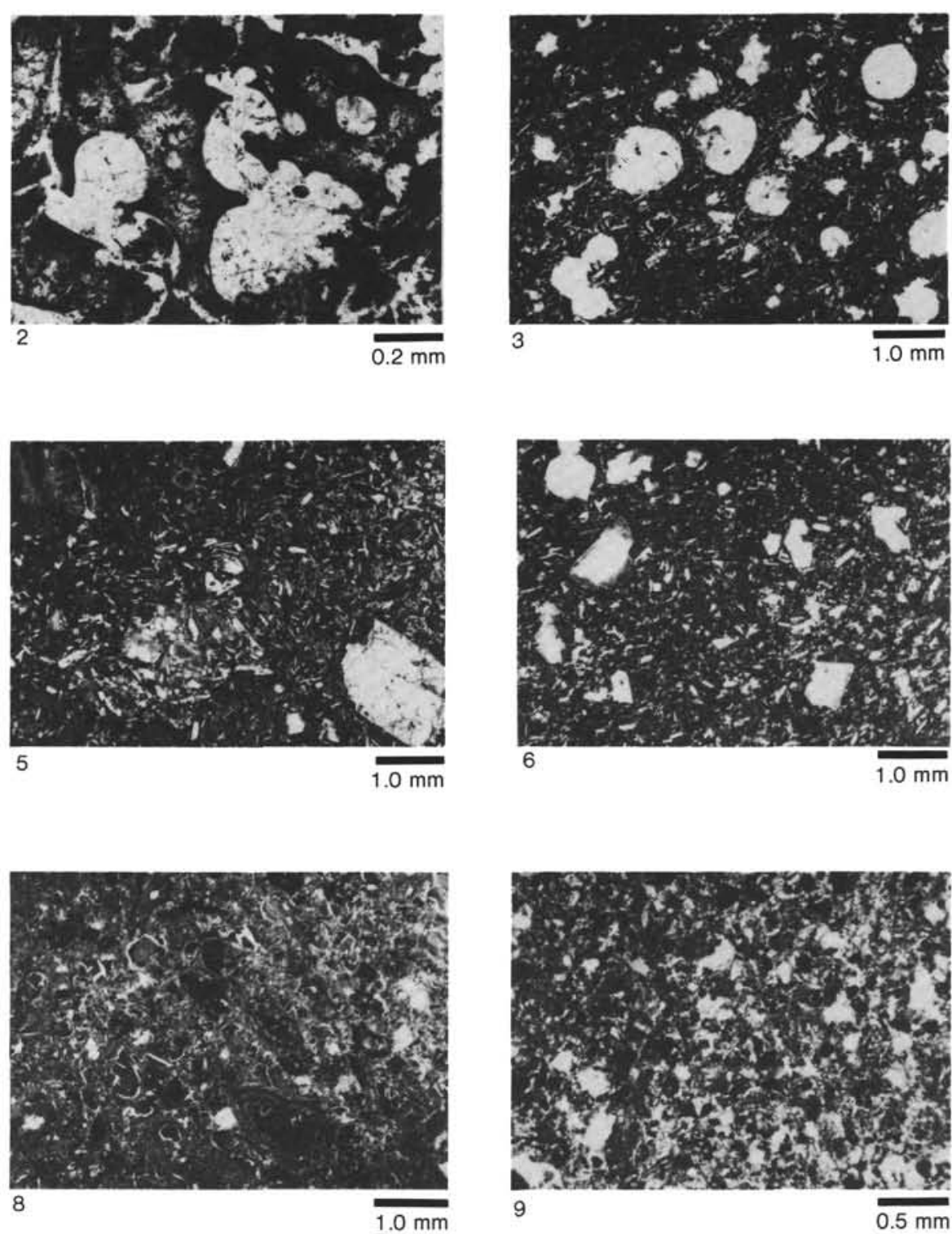

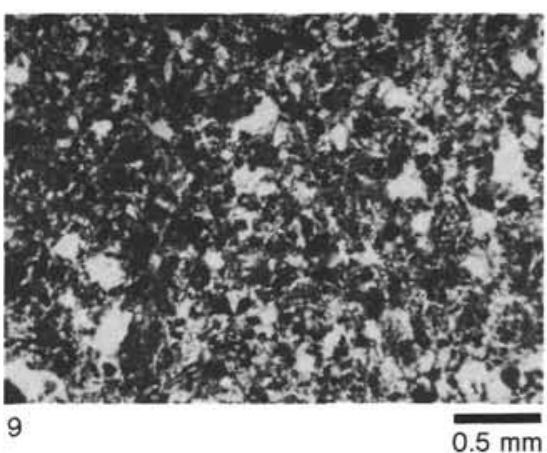

Plate 1. Photomicrographs illustrating petrographic features of the extracted glassy and basaltic clasts (ppl = plane polarized light; $\mathrm{xp}=\mathrm{crossed}$ polars): 1. sample number 1 -altered vesicular phyric glass shards in fine-grained smectitic matrix. Sample 585-48-1, 141-144 cm (ppl). 2 . sample number 2-vesicular smectite shards in zeolitized matrix. Sample 585A-18-7, 46-50 cm (ppl). 3. sample number 3-vesicular portion of sparsely plagioclase phyric basalt; vesicles infilled with radiate celadonite. Sample 585A-20-2, 121-123 cm (ppl). 4. sample number 4-nonvesicular sparsely plagioclase phyric basalt. Sample $585 \mathrm{~A}-20-2,124-128 \mathrm{~cm}$ (xp). 5. sample number 5-vesicular plagioclase-olivine phyric basalt; phenocrystic plagioclase is relatively fresh (white), whereas olivine (gray to black) is alteration veined. Sample $585 \mathrm{~A}-21-1,1-4 \mathrm{~cm}$ (ppl). 6. sample number 6-fine-grained plagioclase-olivine phyric basalt; phenocrystic olivine is not in evidence here and much of the plagioclase is altered. Sample 585A-21-2, 52-58 cm (ppl). 7. sample number 7-alteration-cored plagioclase microphenocrysts in quenched matrix dominated by plagioclase microlites. Sample 585A-21-2, 61-65 cm (ppl). 8. sample number 8-hyaloclastite composed of palagonitized shards and dark tachylite fragments in smectite matrix. Sample 585A-22,CC $(34-40 \mathrm{~cm})(\mathrm{ppl})$. 9. sample number 9-hyaloclastite with angular altered glass fragments. Sample 585A-22,CC (49-52 cm) (ppl). 